\title{
Dental problems and its epidemiological factors ----a study on adolescent and adult patients attending dental OPD of a tertiary care hospital in Kolkata, India.
}

\author{
${ }^{1}$ Dr. Urmila Dasgupta, ${ }^{2}$ Dr. Sarmila Mallik, ${ }^{3}$ Dr. Subhrajyoti Naskar, \\ ${ }^{4}$ Dr. Kantibhusan Choudhury, ${ }^{5}$ Dr. Baishakhi Paria , ${ }^{6}$ Dr. Salil Kumar \\ Bhattacharya \\ ${ }^{1}$ Associate Professor, Dept. of Community Medicine, Medical College, Kolkata \\ ${ }^{2}$ Associate Professor, Dept. of Community Medicine, Calcutta National Medical College,Kolkata \\ ${ }^{3}$ Assistant Professor, Dept. of Community Medicine, Malda Medical College, Malda \\ ${ }^{4}$ Assistant Professor, Dept. of Community Medicine, Calcutta National Medical College,Kolkata \\ ${ }^{5}$ Demonstrator Dept. of Community Medicine, Calcutta National Medical College, Kolkata \\ ${ }^{6}$ Professor,Dept. of Community Medicine, Calcutta National Medical College, Kolkata
}

\begin{abstract}
Background: According to the World Health Organization(WHO) the "Promotion of oral health is a cost-effective strategy to reduce the burden of oral disease and maintain oral health and quality of life. It is also an integral part of health promotion in general, as oral health is a determinant of general health and quality of life. Objectives: To find out proportion of different types of common dental problems identified during the study period in dental OPD, to identify socio demographic factors related to dental problems and to assess the relationship between oral hygiene practices and common dental problems, if any. Study settings: Dental out patient department of Calcutta National Medical College \& Hospital, Kolkata,India. Study design: Hospital based cross sectional observational study. Study population: Patients aged 10 years and above, attending dental OPD. Methodology: By systematic random sampling 366 patients were selected for interview. Sociodemographic information, type of dental problems, practices regarding maintenance of oral hygiene were recorded and analysed. Results: Maximum number of study subjects presenting with dental problems were in the age group of 30-39 and $40-49$ years(24.6\% and $20.2 \%$ respectively), $56.3 \%$ were females, and $35.8 \%$ were illiterate and just literate. $53.6 \%$ of patients used to brush their teeth twice or more, in $39.0 \%$ of subjects technique of brushing was horizontal, it was circular in $24.6 \%$, Oral rinsing after every meal was done by $61.2 \%$ patients, and after major meals in 19.1\%. 68.9\% of total study subjects had dental caries, $50.8 \%$ had gingivitis and $32.2 \%$ had abrasion of teeth. Tobacco chewing was positively related to dental caries whereas increasing age positively influenced teeth abrasion. Brushing in circular direction and frequent oral rinsing were found to be protective against dental problems.
\end{abstract}

key words: Dental caries, gingivitis, teeth abrasion.

Good health depends on a wide variety of factors, including oral health. According to the World Health Organization(WHO) the "Promotion of oral health is a cost-effective strategy to reduce the burden of oral disease and maintain oral health and quality of life. It is also an integral part of health promotion in general, as oral health is a determinant of general health and quality of life."1

The WHO Global Oral Health Programme clearly articulates that a new strategy of disease prevention and promotion of health is consistent with their overall strategies for global health. ${ }^{2}$ Poor oral hygiene can actually lead to other health problems, including: Oral and facial pain. ---According to the Office of the Surgeon General, this pain may be largely due to infection of the gums that support the teeth and can lead to tooth loss. Gingivitis, an early stage of gum disease, and advanced gum disease affect more than 75 percent of the U.S. population. Problems with the heart and other major organs-- Mouth infections can affect major organs. For example, the heart and heart valves can become inflamed by bacterial endocarditis, a condition that affects people with heart disease or anyone with damaged heart tissue. Digestion problems-- Digestion begins with physical and chemical processes in the mouth, and problems here can lead to intestinal failure, irritable bowel syndrome and other digestive disorders. ${ }^{3}$

Proper brushing is essential for cleaning teeth and gums effectively. Brushing teeth for two minutes at least twice a day remains a critical component to maintain a healthy smile. Studies have shown that brushing for two minutes is perhaps the single most important step an individual can take to reduce plaque build-up and the risk of plaque-associated diseases, such as cavities and gingivitis. Proper brushing is essential for cleaning teeth and gums effectively. ${ }^{4}$ Incidence of dental problems are affected by factors like age, sex, residence, materials and mechanism of brushing, oral rinsing, food habits to newly observed factors like hyperacidity and even 
professional DEN5QL CARE. ${ }^{5,6}$ In spite of the universal distribution of Caries and Periodontal diseases ,they are highly prevalent in under developed countries than in developed ones. ${ }^{7}$ Hence, oral hygiene is a part of total body cleanliness and people desire fresh and healthy mouth with good smelling breath. Considering these, the present study was done with following objectives:

To find out proportion of different types of common dental problems identified among the adolescent and adult patients attending the dental OPD in a tertiary care hospital in Kolkata

To identify socio demographic factors related to dental problems

To assess the relation of oral hygiene practices with common dental problems, if any.

\section{Methodology:}

A hospital based cross-sectional observational study was carried out in the Dental O.P.D of Calcutta National Medical College \& Hospital in Kolkata. Data were collected from June 2010 to August 2010 from adolescent and adult patients attending the Dental O.P.D during data collection period and who were willing to participate.

Data were collected in the predesigned, pretested, semi-structured schedule by exit interview either from patient or from accompanying guardians in case of patient $\leq 14$ years.

Dental diagnosis by qualified dentists from the O.P.D tickets was recorded. Common dental problems included were Dental caries, gingivitis and abrassion. The schedule included socio-demographic factors like age, sex, residence, occupation, literacy status, socio-economic status, personal characteristics like addiction, oral hygiene . Socio economic class of respondents was determined according to modified B.G.Prasad Scale(again modified by A.K.Agarwal) ${ }^{8}$.Time taken for completing each schedule was on average 30 minutes. Daily O.P.D. attendance of adolescent and adult patients in this dental clinic was 20-30 per day. During O.P.D. hours 4-5 patients per day were interviewed and interview was taken 6 days a week. By systematic random sampling every forth patients were interviewed after taking consent, if patient was unwilling, next patient was interviewed. Total 366 patients were interviewed. Data entry was done in MS-EXCEL and was analyzed by SPSS 16.

\section{Results:}

Table 1 shows that maximum number of study subjects presenting with dental problems were in the age group of 30-39 and $40-49$ years( $24.6 \%$ and $20.2 \%$ respectively). $14.5 \%, 18.3 \%, 13.7 \%$ and $8.7 \%$ patients were in the age group of 10-19,20-29,50-59 and $\geq 60$ years respectively.56.3\% study subjects were females and rest $(43.7 \%)$ were males. Regarding education illiterate and just literate patients comprised the largest group(35.8\%) followed by those with secondary education(27.8\%). $25.1 \%$ and $12.1 \%$ patients were with educational status primary and higher secondary or above respectively. Regarding occupation maximum number of study subjects were housewives(33.3\%).Other occupational groups comprised of service $(12.6 \%)$, business(10.7\%), skilled worker (14.2\%), non skilled worker(16.4\%), and students(12.8\%). $25.7 \%$ patients belonged to socio-economic class I followed by those in class IV(23.5\%). 17.2\%,19.4\%, and $14.2 \%$ patients belonged to socio-economic classes II,III and V respectively. Majority of the study population came from urban area(75.4\%), only $24.6 \%$ came from rural area. $46.4 \%$ patients were without any addiction, $13.4 \%$ had the habit of chewing pan, $10.7 \%$ were addicted to tobacco chewing, $16.4 \%$ to smoking tobacco and $13.1 \%$ had the addiction of both chewing and smoking tobacco. Table II shows that $46.4 \%$ patients used to brush their teeth once, whereas $53.6 \%$ twice or more. Brushing teeth before breakfast, after lunch, after dinner, and after every meal was found in $77.3 \%, 13.1 \%, 42.6 \%$ and $8.7 \%$ patients, respectively. In $39.0 \%$ of subjects technique of brushing was horizontal, it was circular in $24.6 \%$ and without any particular direction in $36.4 \%$. Oral rinsing after every meal was done by $61.2 \%$ patients, it was done after major meals in $19.1 \%$, and occasionally in $7.7 \%$, and $12.0 \%$ patients didn't respond to this question. From tables III\& IV it was found that $68.9 \%$ of the patients had dental caries,50.8\% had gingivitis and 32.2\% had abrasion of teeth. Percentage of patients suffering from dental caries was around 73 to $75 \%$ in the age group of 10 to 39 years, it was around 56 to58\% in patients aged 50 years and above.66.2\% of dental caries patients were in the age group of $40-49$ years. The difference of frequency of dental caries in different age groups were not significant $(\mathrm{p}>0.05)$. Frequency of gingivitis varied from $43 \%$ to $50 \%$ in different age groups except in the age group of 30-39 years where the frequency was $61.1 \%$.The differences were not statistically significant. It was found that percentage of patients suffering from teeth abrasion increased with increase in age, lowest(7.5\%) in the age group of 10-19 years and highest $\geq 60$ years $(65.6 \%)$, in other age groups frequency varied from $25 \%$ to $48 \%$. The difference of frequency in different age groups was statistically significant $(p<0.05)$.Frequency of dental caries showed little difference $(p>0.05)$ in different educational status, around $64 \%$ to $73 \%$ was the frequency of dental caries in different educational groups. Frequency of gingivitis was around 51 to $60 \%$ in illiterate, just literate, primary and secondary education groups where as it was low $(25.0 \%)$ in educational group H.S and above. The difference of frequency of gingivitis amongst different educational groups was statistically significant $(\mathrm{p}<0.05)$ and it was mainly due to 
H.S and above group. Dental abrasion was $39.7 \%$ in illiterate and just literate patients and varied from $27-32 \%$ in other educational groups. The differences were not statistically significant. Frequency of dental caries was significantly higher $(\mathrm{p}<0.05)$ in patients chewing tobacco(74.4\%) than those addicted to pan only(53.1\%).61.7\% and,68.8\% patients having addiction of tobacco smoking and both tobacco chewing and smoking respectively had dental caries. Surprisingly $74.7 \%$ of persons without addiction had dental caries.Gingivitis was found in $61.2 \%, 46.2 \%, 58.3 \%$ and $45.8 \%$ of study subjects addicted to only pan, tobacco chewing, tobacco smoking and both tobacco chewing and smoking respectively. In patients without addiction gingivitis was observed in $47.6 \%$. Teeth abrasion was present in $44.9 \%, 43.6 \%, 40.0 \%$ and $25.1 \%$ of persons with the addiction of only pan, tobacco chewing, tobacco smoking and both tobacco chewing and smoking respectively.25.3\% patients without addiction had dental abrasion. Addiction did not significantly influence gingivitis and teeth abrasion. Frequency of dental caries was $72.4 \%$ and $65.8 \%$ in those who used to brush teeth once and twice or more respectively Almost equal proportion of patients $(51.8 \%$ and $50.0 \%)$ had gingivitis in both groups. $25.3 \%$ of patients brushing teeth once and $38.3 \%$ patients brushing teeth twice or more had abrasion of teeth. There was no significant difference in frequency of these three types of dental problems with frequency of brushing. Occurrence of dental caries and gingivitis was significantly lower $(\mathrm{p}<0.05)$ in patients brushing teeth circular direction . Among patients brushing teeth in horizontal direction, $78.3 \%$ had dental caries. $48.9 \%$ brushing in circular direction and $72.2 \%$ brushing in no particular direction had dental caries . Frequency of gingivitis was $63.6 \%, 22.2 \%$ and $56.4 \%$ in persons brushing teeth horizontally ,circularly and without any particular direction respectively. Teeth abrasion was present in significantly higher proportion $(67.1 \%)$,in patients brushing teeth horizontally than those brushing in circular direction(10.0\%), or without any particular direction $(9.8 \%)$. $66.1 \%$ with oral rinsing after every meal, $78.6 \%$ with oral rinsing after major meals, $96.4 \%$ with occasional rinsing, $50.0 \%$ without responding had dental caries.Excluding no response group it was found oral rinsing had significant effect on dental caries. Frequency of gingivitis was around 47 to $53 \%$ in these four groups without any significant difference . $31.7 \%$ with oral rinsing after every meal, $28.6 \%$ with oral rinsing after major meals, $57.1 \%$ with occasional rinsing, $25.0 \%$ without responding had teeth abrasion. Dental caries and teeth abrasion occurred with significant higher frequency in those rinsing teeth occasionally.

\section{Discussion:}

In the present study no significant difference was found in the occurrence of dental caries and gingivitis in different age groups, but the frequency of dental abrasion was significantly higher in higher age group. According to American Dental Association dental caries remain the most common chronic disease of children aged 6 to 11 years and adolescents aged 12 to 19 years. ${ }^{9}$ According to Dye BA et al. dental caries also affects adults, with 9 out of 10 over the age of 20 having some degree of tooth-root decay. ${ }^{10}$ In this study educational status did not have any significant relation with dental caries and teeth abrasion, but in case of gingivitis there was significant difference and it was due to the group of H.S \& above educational status. According to Selwitz et al. dental caries have been linked with lower socioeconomic status ${ }^{11}$ This study found significant difference in the frequency of dental caries among those who were addicted to pan only and those who had the habit of tobacco chewing but not among other groups and when compared to patients without addiction. For gingivitis and teeth abrasion there was no significant difference in frequency among different types of addiction like pan only, tobacco chewing, tobacco smoking, both tobacco chewing and smoking. Neville et al. in their study observed that the use of tobacco increase the risk for caries formation and some brands of smokeless tobacco contain high sugar content increasing susceptibility to caries. ${ }^{12}$ According to Banting D.W. and America Academy of Periodontology tobacco use is a significant risk factor for periodontal diseases. which can cause the 3ingival to recede. ${ }^{13,14}$ According to U.S. Surgeon General's report, there is not enough evidence to support a causal relationship between smoking and coronal caries, but evidence does suggest a relationship between smoking and root surface caries. ${ }^{15}$ The present study found that more than half of the study subjects used to brush teeth twice or more in a day. Frequency of brushing was not significantly related to dental problems, caries, gingivitis and dental abrasion. Brushing in circular direction was practised by only $24.6 \%$ of patients. Technique of brushing significantly influenced the occurrence of dental caries, gingivitis and teeth abrasion. Frequency of these diseases were more in those brushing teeth in horizontal direction(78.3\%-dental caries, 63.6\%-gingivitis, $67.1 \%$-teeth abrasion) than those brushing teeth in circular direction(48.9\%-dental caries, $22.2 \%$-gingivitis, $10.0 \%$-teeth abrasion). One third of the study subjects $(31.7 \%)$ had the habit of oral rinsing after every meal and almost same proportion (28.6\%) used to rinse oral cavity after major meals. Frequencies of dental caries and teeth abrasion were significantly higher in those rinsing teeth occasionally $(96.4 \%$ and $57.1 \%$ respectively).According to Centers for disease control and prevention good oral hygiene can help to prevent tooth decay, because dental caries or tooth decay are caused by a breakdown of the tooth enamel. This breakdown is the result of bacteria on teeth that break down food and produce acid that destroys tooth enamel and results in tooth decay. ${ }^{16}$ According to Sheiham A et al. and Watt RG oral hygiene plays an important role in the initiation and progression of dental caries and periodontal diseases. ${ }^{17,18}$ As per Leeds Dental Institute 
Website, the primary focus of brushing and flossing is to remove and prevent the formation of plaque. Plaque consists mostly of bacteria. ${ }^{19}$ According to Andlaw RJ, different studies showed that children with good oral hygiene had a lower caries incidence than those with poor oral hygiene, but the differences were small. ${ }^{20}$ Abiola AA et al. in their study found that caries prevalence was not significantly associated with frequency of tooth brushing, but oral hygiene score was positively correlated with caries prevalence. ${ }^{21}$

\section{Conclusion:}

This study found positive association of dental caries and tobacco chewing and also significant influence of maintaining oral hygiene on dental problems like dental caries, dental abrasion and gingivitis. The best way to keep teeth healthy is to ensure cleaning them regularly, at least twice a day, to get rid of any plaque. It is also important to have a regular check up by the dentist, once every 6 months to one year.

\section{Reference:}

[1]. health: action plan for promotion and integrated disease prevention. New York: World HealthOrganization; 2006

[2]. The Objectives of the WHO Global Oral Health Programme; 2008. [cited Dec 2008]. Available from:http://www.who.int/oral_health/objectives/en/index.html

[3]. http://www.deltadentalins.com/

[4]. National Dental Hygiene Month ,American Dental Hygienists' Association @2012. www.adha.org)

[5]. T.Barman et al,Periodontal condition in adolescent community,Dental oral epidemiology, $1987,15^{\text {th }}$ edition,p-336

[6]. WHO(1994),Tech,Resp.Ser.no.476

[7]. Handerson, D.A World health forum, $1987,8^{\text {th }}$ edition , p-283

[8]. AK Agarwal.Social classification:The need to update in the present scenario. Indian J Community Med 2008;33(1):50-1.

[9]. Centers for Disease Control and Prevention and the American Dental Association. Fluoridation: nature's way to prevent tooth decay. Available at http://www.cdc.gov/Fluoridation/pdf/natures way.pdf

[10]. Dye BA, Tan S, Smith V, Lewis BG, Barker LK, Thornton-Evans G, et al.(2007), Trends in oral health status, United States, 19881994 and 1999-2004. National Center for Health Statistics. Vital Health Stat 11(248).

[11]. Selwitz, R.H Ismail, A.I Pitts(2007). Dental Caries. Lancet 369(9555), 51-59.

[12]. Neville B.W., Douglas Damm, Carl Allen, Jerry Bouquot. “Oral \& Maxillofacial Pathology.” $2^{\text {nd }}$ edition, 2002, p.347. ISBN 0-72169003-3.

[13]. Tobacco Use Increases the Risk of Gum Disease(http://www.perio.org/consumer/smoking.htm), hosted on the America Academy of Periodontology. Page accessed January9,2007.

[14]. Banting D.W. "The Diagnosis of Root Caries(http://www. Nidcr.nih.gov/NR/rdonlyres/5A4386A8-E750-43E9-8450651F4789D09A/0/David_Banting.pdf)."Presentation to the National Institute of Health Consensus Development Conference.p.19. Page accessed August 15,2006.

[15]. Executive Summary(http://www. Cdc.gov/tobacco/sgr/sgr_2004/pdf/executivesummary.pdf) of U.S. Surgeon General's report titled,'The Health Consequences of Smoking: A Report of the Surgeon General," hosted on the CDC(http://www.cdc.gov)website,p12 Page accessed January 9,2007.

[16]. CDC 24/7:Saving Lives. Protecting People.

[17]. Sheiham A, Watt RG. The common risk factor approach: a rational basis for promoting oral health. Community Dent Oral Epidemol 2000;28:399-406

[18]. Watt RG. Emergency theories into the social determinants of health: implications for oral health promotion. Community Dent Oral Epidemiol 2002; 30:241-47

[19]. Introduction to Dental Plaque. Hosted on the Leeds Dental Institute Website. Page accessed August14.2006.

[20]. Andlaw RJ. Oral hygiene and dental caries - a review. Int Dent J.1978Mar;28(1):1-6.

[21]. Abiola AA, Eyitope OO, Sonny O.J, Oyinkan O.S. Dental caries occurrence and associated oral hygiene practices among rural and urban Nigerian pre-school children. Journal of Dentistry and Oral Hygiene.Vol.1(5), pp.64-70. December2009.

TABLE1: Distribution of study population according to socio-demographic profile $\mathrm{N}=366$

\begin{tabular}{|l|l|l|}
\hline Socio-demographic profile & Frequency & Percentage \\
\hline Age groups in years & & \\
\hline $10-19$ & 53 & 14.5 \\
\hline $20-29$ & 67 & 18.3 \\
\hline $30-39$ & 90 & 24.6 \\
\hline $40-49$ & 74 & 20.2 \\
\hline $50-59$ & 50 & 13.7 \\
\hline$\geq 60$ & 32 & 8.7 \\
\hline Gender & & \\
\hline Male & 160 & 43.7 \\
\hline Female & 206 & 56.3 \\
\hline Educational status & & \\
\hline Illiterate \& just literate & 131 & 35.8 \\
\hline Primary & 92 & 25.1 \\
\hline Secondary & 99 & 27.0 \\
\hline H.S \& above & 44 & 12.1 \\
\hline
\end{tabular}


Dental problems and its epidemiological factors ----a study on adolescent and adult patients

\begin{tabular}{|l|l|l|}
\hline Occupation & & \\
\hline Service & 46 & 12.6 \\
\hline Business & 39 & 10.7 \\
\hline Skilled worker & 52 & 14.2 \\
\hline Non-skilled worker & 60 & 16.4 \\
\hline Housewife & 122 & 33.3 \\
\hline Student & 47 & 12.8 \\
\hline Socio-economic status & & \\
\hline I & 94 & 25.7 \\
\hline II & 63 & 17.2 \\
\hline III & 71 & 19.4 \\
\hline IV & 86 & 23.5 \\
\hline V & 52 & 14.2 \\
\hline Residence & & \\
\hline Rural & 90 & 24.6 \\
\hline Urban & 276 & 75.4 \\
\hline Addiction & & \\
\hline Only Pan & 49 & 13.4 \\
\hline Tobacco chewing & 39 & 10.7 \\
\hline Tobacco smoking & 60 & 16.4 \\
\hline Both tobacco chewing \& smoking & 48 & 13.1 \\
\hline Nil & 170 & 46.4 \\
\hline
\end{tabular}

TABLE2:

Distribution of study population according to teeth and oral hygienic practices

\begin{tabular}{|l|l|l|}
\hline Teeth and oral hygienic practices & Frequency & Percentage \\
\hline Frequency of brushing teeth & & \\
\hline Once & 170 & 46.4 \\
\hline Twice or more & 196 & 53.6 \\
\hline Time of brushing teeth* & & \\
\hline Before breakfast & 283 & 77.3 \\
\hline After lunch & 48 & 13.1 \\
\hline After dinner & 156 & 42.6 \\
\hline After every meal & 32 & 8.7 \\
\hline Technique of brushing teeth & & \\
\hline Horizontal & 143 & 39.0 \\
\hline Circular & 90 & 24.6 \\
\hline No particular direction & 133 & 36.4 \\
\hline Frequency of oral rinsing & & \\
\hline After every meal & 224 & 61.2 \\
\hline After major meal & 70 & 19.1 \\
\hline Occasionally & 28 & 7.7 \\
\hline No response & 44 & 12.0 \\
\hline
\end{tabular}

*Multiple responses

TABLE3:

Distribution of study population according to sociodemographic profile and dental problems

\begin{tabular}{|c|c|c|c|c|c|c|c|c|c|c|}
\hline S-D Profile & Tota & \multicolumn{3}{|c|}{ Dental Caries } & \multicolumn{3}{|c|}{ Gingivitis } & \multicolumn{3}{|l|}{ Abrasion } \\
\hline Age group & & Present & Absent & $\begin{array}{l}\mathbf{P} \\
\text { val } \\
\text { ue }\end{array}$ & Present & & $\begin{array}{l}P \\
\text { val } \\
\text { ue }\end{array}$ & Present & Absent & $\begin{array}{l}P \\
\text { val } \\
\text { ve }\end{array}$ \\
\hline $10-19$ & 53 & $40(75.5)$ & $13(24.5)$ & \multirow{5}{*}{$\begin{array}{l}p>0 \\
.05\end{array}$} & $27(50.9)$ & $26(49.1)$ & \multirow{5}{*}{$\begin{array}{l}p> \\
0.0 \\
5\end{array}$} & $4(7.5)$ & $49(92.5)$ & \\
\hline $20-29$ & 67 & $50(74.6)$ & $17(25.4)$ & & $31(46.3)$ & $36(53.7)$ & & $17(25.4)$ & $50(74.6)$ & \\
\hline $30-39$ & 90 & $66(73.3)$ & $24(26.7)$ & & $55(61.1)$ & $35(38.9)$ & & $26(28.9)$ & $64(71.1)$ & \\
\hline $40-49$ & 74 & $49(66.2)$ & $25(33.8)$ & & $36(48.6)$ & $38(51.4)$ & & $26(35.1)$ & $48(64.9)$ & \\
\hline $50-59$ & 50 & $29(58.0)$ & $21(42.0)$ & & $23(46.0)$ & $27(54.0)$ & & $24(48.0)$ & $26(52.0)$ & \\
\hline
\end{tabular}


Dental problems and its epidemiological factors ----a study on adolescent and adult patients

\begin{tabular}{|c|c|c|c|c|c|c|c|c|c|c|}
\hline$\geq 60$ & 32 & $18(56.3)$ & $14(43.7)$ & & $14(43.8)$ & $18(56.2)$ & & $21(65.6)$ & 11(34.4) & \\
\hline Total & 366 & $\begin{array}{l}252(68.9 \\
)\end{array}$ & $\begin{array}{l}\text { 114(31.1 } \\
\text { ) }\end{array}$ & & $186(50.8)$ & $\begin{array}{l}180(49.2 \\
)\end{array}$ & & $\begin{array}{l}118(32.2 \\
)\end{array}$ & $\begin{array}{l}248(67.8 \\
)\end{array}$ & \\
\hline $\begin{array}{l}\text { Educationa } \\
\text { I status }\end{array}$ & & & & & & & & & & \\
\hline $\begin{array}{l}\text { Illiterate \& } \\
\text { just literate }\end{array}$ & 131 & $94(71.8)$ & $37(28.2)$ & \multirow[t]{4}{*}{$\begin{array}{l}p>0 \\
.05\end{array}$} & $68(51.9)$ & $63(48.1)$ & \multirow{4}{*}{$\begin{array}{l}X^{2} \\
=1 \\
4, d \\
f=3 \\
, p= \\
0.0 \\
01\end{array}$} & $52(39.7)$ & $79(60.3)$ & \multirow{4}{*}{$\begin{array}{l}\mathrm{P}> \\
0.0 \\
5\end{array}$} \\
\hline Primary & 92 & $62(67.4)$ & $30(32.6)$ & & $55(59.8)$ & $37(40.2)$ & & $25(27.2)$ & $67(72.8)$ & \\
\hline Secondary & 99 & $64(64.6)$ & $35(35.4)$ & & $52(52.5)$ & $47(47.5)$ & & $27(27.3)$ & $72(72.7)$ & \\
\hline $\begin{array}{ll}\text { H.S } & \& \\
\text { above }\end{array}$ & 44 & $32(72.7)$ & $12(27.3)$ & & $11(25.0)$ & $33(75.0)$ & & $14(31.8)$ & $30(68.2)$ & \\
\hline Total & 366 & $\begin{array}{l}252(68.9 \\
) \\
\end{array}$ & $\begin{array}{l}114(31.1 \\
)^{1}\end{array}$ & & $186(50.8)$ & $\begin{array}{l}180(49.2 \\
)\end{array}$ & & $\begin{array}{l}118(32.2 \\
)\end{array}$ & $\begin{array}{l}248(67.8 \\
) \\
\end{array}$ & \\
\hline Addiction & & & & & & & & & & \\
\hline Only Pan $^{1}$ & 49 & $26(53.1)$ & $23(46.9)$ & \multirow[b]{2}{*}{$\begin{array}{l}\mathrm{X}^{2}= \\
4.2 \\
0, \mathrm{df} \\
=1, \\
\mathrm{p}<0 \\
.05( \\
1-2)\end{array}$} & $30(61.2)$ & 19(38.8) & \multirow{5}{*}{$\begin{array}{l}\text { p> } \\
0.0 \\
5\end{array}$} & 22(44.9) & $27(55.1)$ & \multirow{5}{*}{$\begin{array}{l}\mathrm{p}>0 \\
.05\end{array}$} \\
\hline $\begin{array}{l}\text { Tobacco } \\
\text { chewing }^{2}\end{array}$ & 39 & $29(74.4)$ & $10(25.6)$ & & $18(46.2)$ & $21(53.8)$ & & $17(43.6)$ & $22(56.4)$ & \\
\hline $\begin{array}{l}\text { Tobacco } \\
\text { smoking }\end{array}$ & 60 & $37(61.7)$ & $23(38.3)$ & \multirow{2}{*}{$\begin{array}{l}\text { P> } \\
0.0 \\
5 \\
\text { In } \\
\text { oth } \\
\text { er } \\
\text { cas } \\
\text { es } \\
\end{array}$} & $35(58.3)$ & $25(41.7)$ & & $24(40.0)$ & $36(60.0)$ & \\
\hline $\begin{array}{l}\text { Both } \\
\text { tobacco } \\
\text { chewing \& } \\
\text { smoking }\end{array}$ & 48 & $33(68.8)$ & $15(31.2)$ & & $22(45.8)$ & $26(54.2)$ & & $12(25.1)$ & $36(74.9)$ & \\
\hline Nil & 170 & $\begin{array}{l}127(74.7 \\
\end{array}$ & $43(25.3)$ & & $81(47.6)$ & $89(52.4)$ & & $43(25.3)$ & $\begin{array}{l}127(74.7 \\
\text {. }\end{array}$ & \\
\hline
\end{tabular}

TABLE4

Distribution of study population according to teeth and oral hygienic practices and dental problems

\begin{tabular}{|c|c|c|c|c|c|c|c|c|c|c|}
\hline \multirow{2}{*}{$\begin{array}{l}\text { Teeth and } \\
\text { oral } \\
\text { hygienic } \\
\text { practices } \\
\begin{array}{l}\text { Frequency } \\
\text { of } \\
\text { brushing }\end{array}\end{array}$} & \multirow{2}{*}{$\begin{array}{l}\text { Tota } \\
1\end{array}$} & \multicolumn{3}{|c|}{ Dental Caries } & \multicolumn{3}{|c|}{ Gingivitis } & \multicolumn{3}{|l|}{ Abrasion } \\
\hline & & Present & Absent & $\begin{array}{l}P \\
\text { val } \\
\text { ue }\end{array}$ & Present & Absent & $\begin{array}{l}\text { P } \\
\text { val } \\
\text { ue }\end{array}$ & Present & Absent & $\begin{array}{l}P \\
\text { val } \\
\text { ve }\end{array}$ \\
\hline Once & 170 & $123(72.4)$ & $47(27.6)$ & $\begin{array}{l}p>0 \\
.05\end{array}$ & $88(51.8)$ & $82(48.2)$ & $\begin{array}{l}\mathrm{p}> \\
0.0 \\
5\end{array}$ & $43(25.3)$ & $\begin{array}{l}127(74.7 \\
l^{1}\end{array}$ & $\begin{array}{l}\mathrm{p}> \\
0.0 \\
5\end{array}$ \\
\hline $\begin{array}{l}\text { Twice or } \\
\text { more }\end{array}$ & 196 & $129(65.8)$ & $67(34.2)$ & & $98(50.0)$ & $98(50.0)$ & & $75(38.3)$ & $121(61.7$ & \\
\hline Total & 366 & 252(68.9) & $\begin{array}{l}\text { 114(31.1 } \\
{ }^{2}\end{array}$ & & $\begin{array}{l}186(50.8 \\
)\end{array}$ & $\begin{array}{l}180(49.2 \\
)\end{array}$ & & $\begin{array}{l}118(32.2 \\
)\end{array}$ & $\begin{array}{l}248(67.8 \\
)\end{array}$ & \\
\hline $\begin{array}{l}\text { Technique } \\
\text { of brushing }\end{array}$ & & & & & & & & & & \\
\hline
\end{tabular}


Dental problems and its epidemiological factors ----a study on adolescent and adult patients

\begin{tabular}{|c|c|c|c|c|c|c|c|c|c|c|}
\hline Horizontal & 143 & $112(78.3)$ & $31(21.7)$ & \multirow{3}{*}{$\begin{array}{l}\mathrm{X}^{2} \\
=23 \\
.3, \mathrm{~d} \\
\mathrm{f}=2 \\
, \mathrm{p}< \\
0.0 \\
5\end{array}$} & 91(63.6) & $52(36.4)$ & \multirow{3}{*}{$\begin{array}{l}\mathrm{X}^{2} \\
=4 \\
0.4 \\
9, \mathrm{~d} \\
\mathrm{f}= \\
2, \mathrm{p} \\
<0 . \\
05\end{array}$} & $96(67.1)$ & $47(32.9)$ & \multirow{3}{*}{$\begin{array}{l}\mathrm{X}^{2} \\
=1 \\
30 . \\
7, \mathrm{~d} \\
\mathrm{f}=2 \\
\mathrm{p}< \\
0.0 \\
5\end{array}$} \\
\hline Circular & 90 & $44(48.9)$ & $46(51.1)$ & & $20(22.2)$ & $70(77.8)$ & & $9(10.0)$ & $81(90.0)$ & \\
\hline $\begin{array}{l}\text { No } \\
\text { particular } \\
\text { direction }\end{array}$ & 133 & $96(72.2)$ & $37(27.8)$ & & $75(56.4)$ & $58(43.6)$ & & $13(9.8)$ & $\begin{array}{l}120(90.2 \\
)\end{array}$ & \\
\hline Total & 366 & $252(68.9)$ & $\begin{array}{l}114(31.1 \\
)\end{array}$ & & $\begin{array}{l}186(50.8 \\
)\end{array}$ & $180(49.2$ & & $118(32.2$ & $\begin{array}{l}248(67.8 \\
)\end{array}$ & \\
\hline \multicolumn{11}{|l|}{$\begin{array}{l}\text { Frequency } \\
\text { of oral } \\
\text { rinsing }\end{array}$} \\
\hline $\begin{array}{l}\text { After every } \\
\text { meal }\end{array}$ & 224 & $148(66.1)$ & $76(33.9)$ & \multirow{3}{*}{$\begin{array}{l}\mathrm{X}^{2} \\
=13 \\
.17, \\
\mathrm{df}= \\
2, \mathrm{p} \\
<0 . \\
05\end{array}$} & $\begin{array}{l}114(50.9 \\
\text { ) }\end{array}$ & $110(49.1$ & \multirow{3}{*}{$\begin{array}{l}X^{2} \\
=0 . \\
10, \\
d f \\
=2, \\
\text { p> } \\
0.0 \\
5\end{array}$} & $71(31.7)$ & $153(68.3$ & \multirow{3}{*}{$\begin{array}{l}\mathrm{X}^{2} \\
=8 . \\
13, \\
\mathrm{df}= \\
2, \mathrm{p} \\
<0 . \\
05\end{array}$} \\
\hline $\begin{array}{l}\text { After major } \\
\text { meal }\end{array}$ & 70 & $55(78.6)$ & $15(21.4)$ & & $37(52.9)$ & $33(47.1)$ & & $20(28.6)$ & $50(71.4)$ & \\
\hline $\begin{array}{l}\text { Occasionall } \\
\text { y }\end{array}$ & 28 & $27(96.4)$ & $1(3.6)$ & & $14(50.0)$ & $14(50.0)$ & & $16(57.1)$ & $12(42.9)$ & \\
\hline $\begin{array}{l}\text { No } \\
\text { response }\end{array}$ & 44 & $22(50.0)$ & $22(50.0)$ & & $21(47.7)$ & $23(52.3)$ & & $11(25.0)$ & $33(75.0)$ & \\
\hline Total & 366 & 252(68.9) & 114(31.1 & & $\begin{array}{l}186(50.8 \\
)\end{array}$ & $\begin{array}{l}180(49.2 \\
)\end{array}$ & & $\begin{array}{l}118(32.2 \\
)\end{array}$ & $\begin{array}{l}248(67.8 \\
)\end{array}$ & \\
\hline
\end{tabular}

